\title{
The Past and Present Threat of Avian Influenza in Thailand
}

\author{
Prasert Auewarakul
}

\begin{abstract}
Avian influenza H5N1 infection was first identified in Thailand in January 2004. Since then, there have been three major outbreaks in the cold season of 2003-2004 and in the rainy and cold seasons of 2004-2005 and 2005-2006. More than 62 million birds died or were culled. The burden shifted from large industrial farming in the first outbreak to small farms, backyard chickens, and free-grazing ducks. Up to November 2005, there were 20 confirmed cases of human H5N1 infection. Thirteen of these died. Most of the confirmed cases were solitary ones except for three persons in a single family, and epidemiological evidence indicated that person-to-person transmission may have been involved in this cluster. However, sequence analysis of the virus in the cluster did not suggest any changes that might enhance the viral ability to get transmitted among humans. H5N1 viruses in Thailand and Vietnam belong to a single lineage genetically and are antigenically distinguishable from the viruses of the same genotype $\mathrm{Z}$ from southern China and Indonesia. Despite the seemingly subsiding epidemic in Thailand, the problem is far from resolved. H5N1 viruses are still sporadically isolated from domestic poultry as well as from wildlife. More important, isolates were also found in asymptomatic animals. Natural selection may have adapted the virus to a less aggressive form. This would make the virus more elusive and difficult to control. A threat of a pandemic strain emerging from the H5N1 virus is still imminent.
\end{abstract}

A national strategic plan for avian influenza control and influenza pandemic preparedness has been implemented. The plan aims at effective control of avian influenza spread in animals as well as in humans for a three-year period and at efficient pandemic preparedness within one year. Nevertheless, more regional and international collaboration is needed. With proper collective preparedness, there is a hope that the threatening influenza pandemic can be prevented by confining and eliminating a potential pandemic strain at its origin.

In December 2003, poultry farms in the eastern, central, and northern regions of Thailand experienced large-scale die-offs. The outbreak started from the eastern region of the country. The disease caused rapid death, with a very high attack rate. At that time, H5N1 outbreaks had been reported in South Korea, Vietnam, and Japan (OIE, 2005). A few humans with pneumonia were suspected to originate from contact with sick or dead poultry. Final diagnosis in these patients was not 
done as clinical samples were not available at the time when proper diagnostic testing became available.

On 23 January 2004, the first case of human H5N1 infection in Thailand was reported. It was a boy from Kanchanaburi, a province about $100 \mathrm{~km}$ west of Bangkok. He was admitted to Siriraj Hospital in Bangkok and was diagnosed to have severe progressive pneumonia. The patient was initially treated with broad spectrum antibiotics, and respiratory samples were tested for influenza virus. The laboratory result showed that the patient harbored influenza virus, and sequencing of the viral RNA indicated that the virus belonged to the H5 subtype (Chokephaibulkit et al., 2005; Puthavathana et al., 2005). When this result was reported to the Ministry of Public Health, the government announced that there was a highly pathogenic avian influenza (AI) outbreak in Thailand. The Department of Livestock Development (DLD) confirmed the presence of $\mathrm{H} 5 \mathrm{~N} 1$ viruses in poultry on the same day. Subsequent analysis of the virus from patients and animals confirmed that it was H5N1 AI virus of genotype $\mathrm{Z}$ and was closely related to the virus from Vietnam (Viseshakul et al., 2004; Puthavathana et al., 2005).

\section{The Course of Outbreaks in Humans and Poultry}

Figure 1 shows the time distribution of the outbreak in humans and poultry in Thailand (DLD, 2005a). The outbreak activity has a clear seasonal variation. The disease activity starts at the beginning of the rainy season (July), peaks in October at the transition from the rainy season to winter, and subsides in March when summer starts. The first round of outbreaks in early 2004 was widely spread.

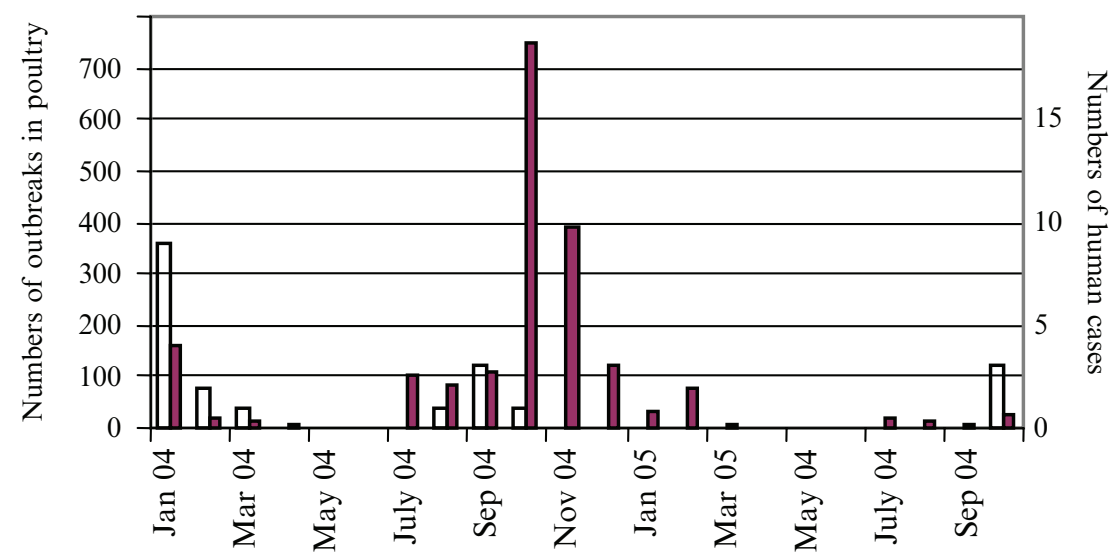

Fig. 1 Time distribution of avian influenza outbreaks in poultry (solid bars) and humans (open bars) in Thailand (DLD, 2005a) 
Subsequent outbreaks in 2004 and 2005 had a more restricted geographical distribution. Most of the outbreaks were in the central and lower northern regions of the country, along the major river basin, where poultry density is the highest, especially free-grazing ducks (Fig. 2). Outbreaks in humans and poultry had similar time and geographical distributions, indicating poultry as the source of infection in humans. Repetitive outbreaks in same areas suggested that even though there was no apparent disease between the outbreaks, the virus remained resident either in domestic animals or wildlife in that area. The similarity of the viruses between the outbreaks further proved that latter outbreaks were caused by the remnant viruses from previous outbreaks and not by a reintroduced virus (Amonsin et al., 2005).

Up to the end of October 2005, there have been a total of 20 confirmed cases in humans, of which 13 died. Of the 20 cases, 12 were in the first round of the outbreak in the winter of 2003-2004, 5 were in the rainy season and winter of 2004, and 3 were in 2005 (Centers for Disease Control and Prevention, 2004; Beigel et al., 2005; Chotpitayasunondh et al., 2005). Besides these 20 cases, there were 23 suspected cases with comparable clinical and epidemiological features but lack laboratory confirmation. Most of the suspected cases were in the early part of the first outbreak when the laboratory test was not readily available and surveillance and specimen referral system had not been well established. They also had direct contact with dying poultry except for one cluster that probably resulted from person-to-person transmission (Ungchusak et al., 2005).
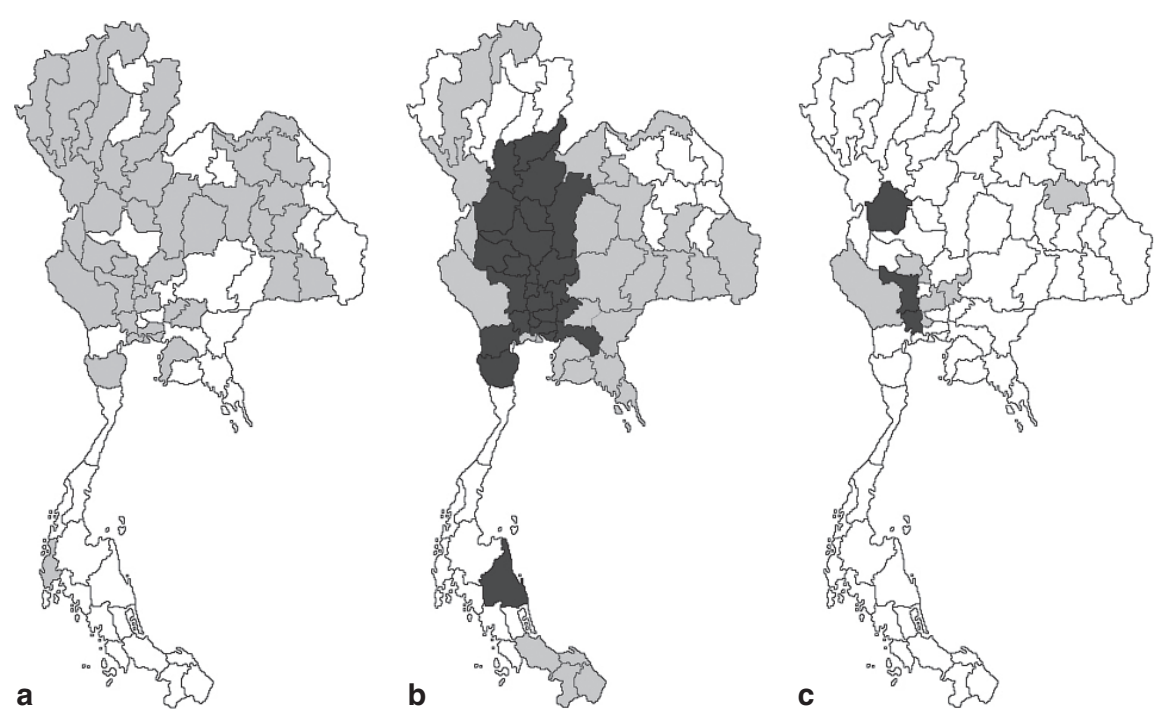

Fig. 2 Geographical distribution of the (a) first (January 2004 to April 2004), (b) second (July 2004 to March 2005), and (c) third rounds of avian influenza outbreaks (July 2005 to September 2005 ) in poultry. In (b) and (c), black and gray shades represent provinces with outbreaks involving more and less than 5,000 birds, respectively (DLD, 2005a) 


\section{Origin and Evolution of the Virus}

All H5N1 AI viruses since the first outbreak in 1997 carry H5 and N1 genes that originated from a common ancestor closely related to a goose virus isolated from Guangdong in 1996 (A/Goose/Gaungdong/1/96) (Li et al., 2004). Although the virus responsible for the 1997 outbreak in Hong Kong was completely eliminated by a total depopulation of poultry on the island, the ancestral virus still circulated in southern China and gave rise to several genotypes by reassortment with other AI viruses. Since 1997, many of these genotypes have emerged, disappeared, and been replaced by other genotypes (Guan et al., 2002, 2004). The genotype Z emerged in 2002 and became the dominant phenotype that caused the explosive outbreak in Southeast Asia in 2003-2004. The genotype Z viruses have multiple sublineages that can categorize Thailand and Vietnam isolates into one cluster and viruses from Indonesia and China into other clusters ( $\mathrm{Li}$ et al., 2004). All the viruses in the outbreaks since 2004 belong to the genotype $\mathrm{Z}$. This suggested that the genotype $\mathrm{Z}$ has the optimal genetic makeup for efficient spread among poultry.

All Thailand isolates contain multiple basic amino acid substitutions at the protease cleavage site in the HA protein, a 20-codon deletion in the NA gene, and a 5-codon deletion in the NS gene, which are characteristics of the genotype $\mathrm{Z}$ viruses. Amino acid residues at the receptor-binding site of HA of human viruses were similar to those of chicken viruses. The presence of amantadine resistance in the Thailand viruses was indicated by a mutation in the M2 transmembrane protein and was phenotypically confirmed. The Thailand viruses contained more avianspecific residues than did the 1997 Hong Kong H5N1 viruses, suggesting that the virus may have adapted to allow a more efficient spread in avian species (Viseshakul et al., 2004; Puthavathana et al., 2005).

It was initially hypothesized that the Thailand-Vietnam clade might be more efficient in causing disease in humans, because there was no human infection in Indonesia earlier in the outbreak, despite extensive spread of the disease in poultry. However, the more recent outbreak of human infection in Indonesia indicated that the Indonesian clade is also pathogenic in man (Kandun et al., 2006). Whether this is a result of viral adaptation or a property of the original virus is unclear.

Influenza is a rapidly evolving virus. Experiments in ducks demonstrated that only a single round of nonlethal infection in one host could exert enough selection pressure to cause an antigenic drift and reduce virulence (Hulse-Post et al., 2005). It is therefore likely that the endemic virus will gradually become less pathogenic in ducks, which is a natural host of influenza virus. Observation of the outbreak pattern in the third round (rainy season 2005) suggested that pathogenicity in other avian species may not be similar to what had been observed in the first round of outbreaks. In the latest outbreak, a smaller fraction of sick and dying animals was observed and more viruses were isolated from apparently healthy animals. Experimental data have shown that the viruses in 2005 were indeed less pathogenic in ducks (Hulse-Post et al., 2005; Sturm-Ramirez et al., 2005). Interestingly, the H5N1 viruses of 1997 were also nonpathogenic in ducks. The virus became pathogenic in ducks in 2002-2003 and 
reverted to a nonpathogenic strain in 2005 (Chen et al., 2004; Sturm-Ramirez et al., 2005). This probably indicated a temporary loss of the equilibrium between the virus and its natural host by the adaptation into a new host, that is, domestic poultry. The reduction of pathogenicity in 2005 suggested that the virus is setting a new equilibrium with its natural host.

\section{Effect on Poultry Industry}

The impact on the poultry industry during the first outbreak was devastating. Because Thailand is a major poultry meat exporting country, direct loss in production caused by the outbreak and culling, the trade ban imposed by importing countries, and reduced domestic consumption caused severe economic loss in the industry. More than 62 million birds were either killed by the disease or culled for outbreak control (Tiensin et al., 2005). The government compensated farmers for their losses. Farmers were entitled to compensation of $75 \%$ of the value of animals that were destroyed. Different sectors of the poultry industry vary in their practice of biosecurity and outbreak prevention. After the first outbreak, most large-scale industries improved biosecurity measures. Consequently, little problem remained in the large-scale industry sector in the second and third outbreaks. The major concern remains in the smallscale backyard farms of chickens and ducks, where it is very difficult to employ proper biosecurity. Another area of concern is the farms in the central part of Thailand, where paddy fields are plentiful. It is a common practice of free-grazing duck raising in Thailand to move flocks of ducks from field to field by trucks to let them feed on the dropped grains after the harvest. Flocks can move over a very long distance in search of a suitable feeding area. Because ducks can be infected and can shed virus without clinical sign, migrating flocks are ideal for spreading the disease (Chen et al., 2004; Sturm-Ramirez et al., 2005). The geographical distribution of the outbreaks coincided with the area with the highest density of free-grazing duck raising (Gilbert et al., 2006). This further supports the belief that free-grazing ducks may have been a major source of the spread of disease.

Another activity that the government has been trying to control is cock fighting. It involves not only the movement of fighting cocks from place to place for fighting, but also close contact between cocks and people, which can increase the chance of transmission to humans. The control measures now in place are registration and the obligatory screening of fighting cocks and temporary prohibition of cock fighting during the peak of influenza outbreaks (DLD, 2005b).

\section{Impact on Wildlife}

Open-bill storks are probably the most affected species in Thailand (Keawcharoen et al., 2005). They are migratory birds that migrate to central Thailand in winter. Some of the birds remain in Thailand all year round. Open-bill storks are vulnerable 
to infection, probably because they live in big flocks in the wetlands of central Thailand. Continuous surveillance confirmed the presence of virus in these birds. Evidence of H5N1 infection was also found in other birds, such as sparrows and pigeons, which share natural habitats with humans and domestic poultry. Although free-living birds are not likely to play a major role in the introduction of new outbreaks, it is possible that these birds may spread the infection locally between farms and maintain the viral reservoir locally between outbreaks.

\section{Disease Manifestation in Humans}

Of the 20 confirmed cases, 11 were children under the age of 14 years and 13 died, leading to a mortality of $65 \%$ (Chotpitayasunondh et al., 2005). In most of the confirmed cases, the source of infection was backyard chickens. Most of the patients had a fever as the starting symptom followed by coughing, dyspnea, and pneumonia in a median time of 4 days. About half of the patients (53\%) had rhinorrhea, $71 \%$ had sore throat, 53\% had myalgia, and $41 \%$ had diarrhea (Chotpitayasunondh et al., 2005). Abnormal chest radiographs in these patients included interstitial infiltration and patchy lobar infiltrates in a variety of patterns (single lobe, multiple lobes, unilateral, or bilateral distributions). In patients who developed ARDS (acute respiratory distress syndrome), the radiographic pattern progressed to a diffuse bilateral ground-glass appearance (Beigel et al., 2005; Chotpitayasunondh et al., 2005). An autopsy study showed that the lung, but not upper airway epithelium, was the site of viral replication, and the cellular target of the virus was the alveolar epithelial cell (Uiprasertkul et al., 2005). The most remarkable laboratory findings in these patients were lymphopenia, leucopenia, and thrombocytopenia. More importantly, the lymphocyte counts were significantly different between fatal cases and survivors and between patients with and without ARDS (Chotpitayasunondh et al., 2005). This suggested that a simple blood count can not only help in the preliminary diagnosis of bird flu, but can also be used as a prognostic marker. Most of these patients were treated with Oseltamivir, but it is not clear whether the treatment changed the course of the illness.

\section{Unusual Disease Manifestation}

Although most confirmed AI infections in humans caused respiratory infection and pneumonia, there were some cases with other manifestations. A case presenting with acute diarrhea and later developing fatal respiratory failure was reported (Apisarnthanarak et al., 2004). Viral replication could be detected in an autopsy sample from the intestine of a patient even in the absence of diarrhea (Uiprasertkul et al., 2005). This suggested that the virus may have a tropism for the intestinal tract similar to the infection in avian species. Reports from Vietnam also showed other unusual manifestations of H5N1 infection in humans, such as encephalitis (de Jong 
et al., 2005). This will make the disease surveillance more difficult, and monitoring of only pneumonia and respiratory failure may not be adequate to cover all cases of human H5N1 infection.

\section{Human-to-Human Transmission and the Risk of Pandemic Disease}

Avian and human influenza viruses were thought to be separated by the receptor preference: avian viruses use 2,3- $\alpha$-linked sialic acid while human viruses use 2,6$\alpha$-linked sialic acid (Suzuki, 2005). H5N1 AI viruses showed avian-type receptor specificity (Matrosovich et al., 1999; Gambaryan et al., 2004). Nevertheless, they can infect humans. Infection by the H5N1 virus in humans is not efficient, and person-to-person transmission cannot readily occur. The inability of the virus to transmit from person to person is the only barrier preventing the virus from becoming a pandemic strain. Experimental data showed that only two substitutions in the receptor-binding site of the hemagglutinin gene are needed to change the receptor-binding preference of $\mathrm{H} 5 \mathrm{~N} 1$ virus from 2,3- to 2,6- $\alpha$-linked sialic acid (Harvey et al., 2004). It is not known whether this receptor preference is the only barrier the virus needs to cross to infect humans efficiently.

Although several clusters of H5N1 infections have been observed in Thailand, Vietnam, and Indonesia, it is difficult to prove human-to-human transmission, as most of these patients had exposure to poultry and it is not possible to prove whether they contracted the disease from animals or humans. The very low sequence variability among the viruses in the outbreak made it impossible to infer chain of transmission from sequence data.

It was a unique incidence in Thailand that allowed an inference of probable person-to-person transmission (Ungchusak et al., 2005). It was a cluster of three patients: a young girl, her mother, and her aunt. The girl and her aunt lived in Kamphaengphet where there was an AI outbreak in poultry. The mother lived in Nonthaburi, a province near Bangkok where there was no AI outbreak and did not have any contact with poultry. She went to take care of her sick daughter 1 day before the girl died. The mother had an onset of fever 4 days later, went back to Nonthaburi, had pneumonia, and died 14 days later. The aunt who also took care of the sick girl also developed pneumonia 8 days after the girl's death. Although she had contact with a dead chicken, the last exposure was 17 days before the onset of fever, which was too long for an incubation period of influenza. Because the mother and the aunt had no contact with poultry within a time interval compatible with an incubation period of influenza and the time of onset after exposure to the index case was compatible with the incubation period of AI, it was concluded that the two cases were likely to contract the disease from the index case (Ungchusak et al., 2005). As soon as this cluster was recognized, effort was made to contain possible further person-to-person transmission. All household members, other family contacts, exposed neighbors, and exposed health care workers were placed under active 
surveillance for fever and respiratory symptoms for 14 days. Fortunately, there was no further transmission or evidence that the virus in this cluster facilitated more efficient human-to-human transmission. However, if the virus is allowed to transmit from humans to humans without interruption, it is likely that it will eventually evolve to become more transmissible in humans. It is therefore crucial that every effort has to be made to prevent human-to-human transmission.

\section{Disease in Mammals}

AI virus $\mathrm{H} 5 \mathrm{~N} 1$ infection was observed in several mammalian species, including cat, tiger, leopard, and dog (Keawcharoen et al., 2004; Thanawongnuwech et al., 2005; Songsermn et al., 2006; Butler, 2006). The exposure that led to the infection was mostly from feeding on the carcasses of infected poultry. The infection caused severe disease, with high mortality in these animals. Experimental infections were also reported in cats, mice, ferrets, monkey, and pigs (Rimmelzwaan et al., 2001, 2003; Kuiken et al., 2003, 2004; Govorkova et al., 2005; Maines et al., 2005). Most of these animals presented severely fatal disease manifestations except for pigs, in which the infection caused only mild disease (Choi et al., 2005). Nevertheless, the virulence of H5N1 virus in mammals is probably heterogeneous among strains and is continuously evolving. Experimental data suggested that the virus is evolving to become more pathogenic in mammals and that the genetic determinants of virulence lie in the polymerase genes, resulting in a high-replication phenotype (Govorkova et al., 2005; Li et al., 2005). This further emphasized the danger of this virus and suggested that it may also become more pathogenic and transmissible in humans.

\section{Control Measure}

Active surveillance of suspected cases is continuously employed by the public health authority in Thailand. Cases of pneumonia in those who have history of exposure to poultry are reported to the Department of Disease Control and investigated for the presence of H5N1 virus by viral culture and RT-PCR. Clusters of pneumonia and pneumonia in hospital personnel are also the targets of surveillance and disease control in order to detect human-to-human transmission of severe influenza of pandemic potential. Emphasis has been made to detect any potential pandemic strain as early as possible. Recent studies using computer simulation predicted that early detection and proper outbreak control by social distancing measures and antiviral drugs may be effective in containing the outbreak and eliminating the potential pandemic virus provided the virus does not have a greater ability to get transmitted than does the previous pandemic strains, that is, it has a basic reproductive number below 1.6-1.8 (Ferguson et al., 2005; Longini 
et al., 2005). The amount of the antiviral drug Oseltamivir that should be enough for the elimination of a potential pandemic virus has been predicted differently between the two studies: 100,000 to 1 million and 3 million courses (Ferguson et al., 2005; Longini et al., 2005). Having that in mind, the Ministry of Public Health has started to stockpile Oseltamivir, and as of October 2005, the amount stockpiled is 72,500 courses $(725,000$ tablets).

Outbreaks in poultry are monitored and controlled by the DLD. Specifically, if the poultry death rate in any facility was greater than $10 \%$ within a single day, all birds, their products, and other potentially contaminated materials have to be destroyed without delay. Cloacal swabs of affected flocks would then be collected for laboratory confirmation. Subsequently, neighboring flocks would be destroyed immediately or quarantined and destroyed when H5N1 laboratory diagnosis was confirmed. Movement of poultry and their products would be restricted to a $1-5-\mathrm{km}$ radius.

In the first round of outbreaks, neighboring flocks within a 5-km radius were preemptively culled as quickly as possible. After July 2004, preemptive culling was implemented only within a village, within an area of $1 \mathrm{~km}$ around an outbreak, or on suspected farms. DLD has launched a nationwide surveillance program (known as "x-ray survey") in January 2004, October 2004, and July 2005. The program was conducted in close collaboration with the Ministry of Agriculture and Cooperatives, Ministry of Public Health, provincial governors, volunteer public health workers, and DLD livestock workers (DLD, 2005b). The program is planned to be launched biannually, in the winter before Chinese New Year and in the rainy season. These two periods are considered the riskiest times of the year because there is an unusually high volume of movement of poultry for the Chinese New Year festivities, which can promote the spreading of the virus. Furthermore, the high humidity and low temperature in the rainy season may be optimal for the viral spread.

Other specific measures include the control of free-grazing ducks and fighting cocks. There have been serious debates over the continuation of raising free-grazing ducks. The practice is favored by environmentalists because it makes efficient use of the paddy field after harvesting and provides biological pest control, as they prey on the golden apple snail, a major pest for rice cultivation. Although the debates are not yet totally resolved, long distance moving of flocks by trucks is temporarily prohibited, especially moving from or into the central region of the country where the disease is not yet fully eliminated. The flocks are registered and allowed to migrate only in a limited zone. The limitation of grazing area by zoning was designed so that there will be no extensive movement, so as to limit the area of potential contamination. The zoning strategy is also implemented to other poultry, dividing the country into five zones: central, north, northeast, east, and south, in order to limit movement of poultry from the central plan to the other regions that are disease-free, especially the eastern region where most exporting poultry industry farms are located.

In contrast to other countries in the region, Thailand does not use the AI vaccine in poultry. Although the illegal vaccine may have been used to some extent, the official policy is still against the vaccine (FAO Newsroom, 2006). 
Although the decision was probably influenced mainly by the international trade barrier, the major scientific concern against vaccination in poultry is the risk of having undetectable asymptomatic infection that may shed the virus and spread the infection (Swayne et al., 2001; Liu et al., 2003). With the changing phenotype of the virus towards lower virulence in ducks, the vaccination policy may need to be reconsidered, because without vaccination the ducks will be asymptomatically infected as well and vaccination is effective in reducing the level of viral shedding (Tian et al., 2005). A previous report showing the ability of vaccination to abort an outbreak in a chicken farm strongly supports the use of the vaccine in adjunction to biosecurity measures (Ellis et al., 2004).

Sufficient facility for viral testing is crucial for the success of outbreak control and surveillance. Both the National Institute of Health and the National Institute of Animal Health have strengthened their diagnostic capability and extended the service to their regional laboratories.

\section{National Influenza Plan}

Two national plans, National Strategic Plan for Avian Influenza Control and National Strategic Plan for Influenza Pandemic Preparedness for a 3-year period (2005-2007), have been set and endorsed by the cabinet since January 2005 (Wibulpolprasert et al., 2005).

The National Strategic Plan for Avian Influenza Control has targets within the 3-year period as follows:

1. No outbreak of AI in economic poultry in 2 years.

2. Reduce outbreak in domestic poultry, fighting cocks, exotic birds, and migratory birds to a level that is not considered a problem in 3 years.

3. No outbreak in other animals in 3 years.

4. No disease contract from animals to humans in 2 years.

5. Thailand is efficiently prepared to handle an influenza pandemic in 1 year.

The National Strategic Plan for Influenza Pandemic Preparedness has targets within the 3-year period as follows:

1. To strengthen an effective influenza surveillance system, including clinical surveillance in the communities, work places, educational institutions, and every public health facilities, as well as establishing 12 centers for laboratory surveillance of the viruses throughout the country within 3 years.

2. To enable Thailand to be ready for efficient management of the emergency situations during the influenza pandemic within 2 years.

3. To stockpile antiviral drugs (Oseltamivir) so as to treat 325,000 patients $(3,250,000$ tablets $)$ and to stockpile the raw materials for manufacturing antiviral drugs (Oseltamivir) so as to treat 1,625,000 patients within 5 years.

4. To develop the capacity to manufacture or stockpile influenza vaccines within 5 years. 
5. In case of an influenza pandemic, hospitals throughout the country have the capacity of up to 100,000 beds for taking care of influenza patients in critical conditions. In case of outbreaks in specific areas, field hospitals with a capacity of 5,000 beds will be ready for services.

The threat of influenza pandemic is eminent. While any AI virus has a potential to evolve and eventually become a pandemic strain, the present danger is the H5N1 virus, which has already crossed the interspecies barrier from avian to human. Without proper intervening measures, it is just a matter of time before the virus adapts to transmit efficiently from person to person and become the next pandemic virus. Effective control of the outbreak in animals, prevention of exposure in humans, and early detection of a potential pandemic strain are essential to the success of preventing the pandemic. Preparedness in case of a pandemic is also crucial to minimize the loss of human life. Strong international collective effort is essential for the success.

\section{References}

Amonsin, A., Payungporn, S., Theamboonlers, A., Thanawongnuwech, R., Suradhat, S., Pariyothorn, N., Tantilertcharoen, R., Damrongwantanapokin, S., Buranathai, C., Chaisingh, A., Songserm, T., \& Poovorawan, Y. (2005). Genetic characterization of H5N1 influenza A viruses isolated from zoo tigers in Thailand. Virology, $26 \mathrm{Sep}$ [Epub ahead of print].

Apisarnthanarak, A., Kitphati, R., Thongphubeth, K., Patoomanunt, P., Anthanont, P., Auwanit, W., Thawatsupha, P., Chittaganpitch, M., Saeng-Aroon, S., Waicharoen, S., Apisarnthanarak, P., Storch, G. A., Mundy, L. M., \& Fraser, V. J. (2004). Atypical avian influenza (H5N1). Emerg Infect Dis, 10, 1321-4.

Beigel, J. H., Farrar, J., Han, A. M., Hayden, F. G., Hyer, R., de Jong, M. D., Lochindarat, S., Nguyen, T. K., Nguyen, T. H., Tran, T. H., Nicoll, A., Touch, S., \& Yuen, K. Y. (2005). Avian influenza A (H5N1) infection in humans. N Engl J Med, 353, 1374-85.

Butler, D. (2006). Thai dogs carry bird-flu virus, but will they spread it? Nature, 439, 773.

Centers for Disease Control and Prevention. (2004). Cases of influenza A (H5N1) - Thailand, 2004. MMWR Morb Mortal Wkly Rep, 53, 100-3.

Chen, H., Deng, G., Li, Z., Tian, G., Li, Y., Jiao, P., Zhang, L., Liu, Z., Webster, R. G., \& Yu, K. (2004). The evolution of H5N1 influenza viruses in ducks in southern China. Proc Natl Acad Sci U S A, 101, 10452-7.

Choi, Y. K., Nguyen, T. D., Ozaki, H., Webby, R. J., Puthavathana, P., Buranathal, C., Chaisingh, A., Auewarakul, P., Hanh, N. T., Ma, S. K., Hui, P. Y., Guan, Y., Peiris, J. S., \& Webster, R. G. (2005). Studies of H5N1 influenza virus infection of pigs by using viruses isolated in Vietnam and Thailand in 2004. J Virol, 79, 10821-5.

Chokephaibulkit, K., Uiprasertkul, M., Puthavathana, P., Chearskul, P., Auewarakul, P., Dowell, S. F., \& Vanprapar, N. (2005). A child with avian influenza A (H5N1) infection. Pediatr Infect Dis $J, 24,162-6$.

Chotpitayasunondh, T., Ungchusak, K., Hanshaoworakul, W., Chunsuthiwat, S., Sawanpanyalert, P., Kijphati, R., Lochindarat, S., Srisan, P., Suwan, P., Osotthanakorn, Y., Anantasetagoon, T., Kanjanawasri, S., Tanupattarachai, S., Weerakul, J., Chaiwirattana, R., Maneerattanaporn, M., Poolsavathitikool, R., Chokephaibulkit, K., Apisarnthanarak, A., \& Dowell, S. F. (2005). Human disease from influenza A (H5N1), Thailand, 2004. Emerg Infect Dis, 11, 201-9.

de Jong, M. D., Bach, V. C., Phan, T. Q., Vo, M. H., Tran, T. T., Nguyen, B. H., Beld, M., Le, T. P., Truong, H. K., Nguyen, V. V., Tran, T. H., Do, Q. H., \& Farrar, J. (2005). Fatal avian 
influenza A (H5N1) in a child presenting with diarrhea followed by coma. $N$ Engl J Med, $352,686-91$.

DLD. (2005a). Date of updating: 31 October 2005. Department of Livestock Development. Date of access: 31 October 2005, http://www.dld.go.th/home/bird_flu/history.html

DLD. (2005b). Date of posting: 20 July 2005. Department of Livestock Development. Date of access: 31 October 2005, http://www.dld.go.th/home/duck/chick\&duck.pdf

Ellis, T. M., Leung, C. Y., Chow, M. K., Bissett, L. A., Wong, W., Guan, Y., \& Malik Peiris, J. S. (2004). Vaccination of chickens against H5N1 avian influenza in the face of an outbreak interrupts virus transmission. Avian Pathol, 33, 405-12.

FAO Newsroom. (2006). Thailand shares secrets of success. Date of posting: 21 July 2006. FAO. Date of access: 1 January 2007, http://www.fao.org/newsroom/en/focus/2006/1000348/article_ 1000352en.html

Ferguson, N. M., Cummings, D. A., Cauchemez, S., Fraser, C., Riley, S., Meeyai, A., Iamsirithaworn, S., \& Burke, D. S. (2005). Strategies for containing an emerging influenza pandemic in Southeast Asia. Nature, 437, 209-14.

Gambaryan, A. S., Tuzikov, A. B., Pazynina, G. V., Webster, R. G., Matrosovich, M. N., \& Bovin, N. V. (2004). H5N1 chicken influenza viruses display a high binding affinity for Neu5Acalpha2-3Galbeta1-4(6-HSO(3))GlcNAc-containing receptors. Virology, 326, 310-6.

Gilbert, M., Chaitaweesub, P., Parakamawongsa, T., Premashthira, S., Tiensin, T., Kalpravidh, W., Wagner, H.,\& Slingenbergh, J. (2006). Free-grazing ducks and highly pathogenic avian influenza, Thailand. Emerg Infect Dis, 12, 227-34.

Govorkova, E. A., Rehg, J. E., Krauss, S., Yen, H. L., Guan, Y., Peiris, M., Nguyen, T. D., Hanh, T. H., Puthavathana, P., Long, H. T., Buranathai, C., Lim, W., Webster, R. G., \& Hoffmann, E. (2005). Lethality to ferrets of H5N1 influenza viruses isolated from humans and poultry in 2004. J Virol, 79, 2191-8.

Guan, Y., Peiris, J. S., Lipatov, A. S., Ellis, T. M., Dyrting, K. C., Krauss, S., Zhang, L. J., Webster, R. G., \& Shortridge, K. F. (2002). Emergence of multiple genotypes of H5N1 avian influenza viruses in Hong Kong SAR. Proc Natl Acad Sci U S A, 99, 8950-5.

Guan, Y., Poon, L. L., Cheung, C. Y., Ellis, T. M., Lim, W., Lipatov, A. S., Chan, K. H., SturmRamirez, K. M., Cheung, C. L., Leung, Y. H., Yuen, K. Y., Webster, R. G., \& Peiris, J. S. (2004). H5N1 influenza: A protean pandemic threat. Proc Natl Acad Sci U S A, 101, 8156-61.

Harvey, R., Martin, A. C., Zambon, M., \& Barclay, W. S. (2004). Restrictions to the adaptation of influenza a virus h5 hemagglutinin to the human host. $J$ Virol, 78, 502-7.

Hulse-Post, D. J., Sturm-Ramirez, K. M., Humberd, J., Seiler, P., Govorkova, E. A., Krauss, S., Scholtissek, C., Puthavathana, P., Buranathai, C., Nguyen, T. D., Long, H. T., Naipospos, T. S., Chen, H., Ellis, T. M., Guan, Y., Peiris, J. S., \& Webster, R. G. (2005). Role of domestic ducks in the propagation and biological evolution of highly pathogenic H5N1 influenza viruses in Asia. Proc Natl Acad Sci U S A, 102, 10682-7.

Kandun, I. N., Wibisono, H., Sedyaningsih, E. R., Yusharmen, Hadisoedarsuno, W., Purba, W., Santoso, H., Septiawati, C., Tresnaningsih, E., Heriyanto, B., Yuwono, D., Harun, S., Soeroso, S., Giriputra, S., Blair, P. J., Jeremijenko, A., Kosasih, H., Putnam, S. D., Samaan, G., Silitonga, M., Chan, K. H., Poon, L. L., Lim, W., Klimov, A., Lindstrom, S., Guan, Y., Donis, R., Katz, J., Cox, N., Peiris, M., \& Uyeki, T. M. (2006). Three Indonesian clusters of H5N1 virus infection in 2005. N Engl J Med, 355, 2186-94.

Keawcharoen, J., Oraveerakul, K., Kuiken, T., Fouchier, R. A., Amonsin, A., Payungporn, S., Noppornpanth, S., Wattanodorn, S., Theambooniers, A., Tantilertcharoen, R., Pattanarangsan, R., Arya, N., Ratanakorn, P., Osterhaus, D. M., \& Poovorawan, Y. (2004). Avian influenza H5N1 in tigers and leopards. Emerg Infect Dis, 10, 2189-91.

Keawcharoen, J., Amonsin, A., Oraveerakul, K., Wattanodorn, S., Papravasit, T., Karnda, S., Lekakul, K., Pattanarangsan, R., Noppornpanth, S., Fouchier, R. A., Osterhaus, A. D., Payungporn, S., Theamboonlers, A., \& Poovorawan, Y. (2005) Characterization of the hemagglutinin and neuraminidase genes of recent influenza virus isolates from different avian species in Thailand. Acta Virol, 49, 277-80. 
Kuiken, T., Rimmelzwaan, G. F., Van Amerongen, G., \& Osterhaus, A. D. (2003). Pathology of human influenza A (H5N1) virus infection in cynomolgus macaques (Macaca fascicularis). Vet Pathol, 40, 304-10.

Kuiken, T., Rimmelzwaan, G., van Riel, D., van Amerongen, G., Baars, M., Fouchier, R., \& Osterhaus, A. (2004). Avian H5N1 influenza in cats. Science, 306, 241.

Li, K. S., Guan, Y., Wang, J., Smith, G. J., Xu, K. M., Duan, L., Rahardjo, A. P., Puthavathana, P., Buranathai, C., Nguyen, T. D., Estoepangestie, A. T., Chaisingh, A., Auewarakul, P., Long, H. T., Hanh, N. T., Webby, R. J., Poon, L. L., Chen, H., Shortridge, K. F., Yuen, K. Y., Webster, R. G., \& Peiris, J. S. (2004). Genesis of a highly pathogenic and potentially pandemic H5N1 influenza virus in eastern Asia. Nature, 430, 209-13.

Li, Z., Chen, H., Jiao, P., Deng, G., Tian, G., Li, Y., Hoffmann, E., Webster, R. G., Matsuoka, Y., \& Yu, K. (2005). Molecular basis of replication of duck H5N1 influenza viruses in a mammalian mouse model. J Virol, 79, 12058-64.

Liu, M., Wood, J. M., Ellis, T., Krauss, S., Seiler, P., Johnson, C., Hoffmann, E., Humberd, J., Hulse, D., Zhang, Y., Webster, R. G., \& Perez, D. R. (2003). Preparation of a standardized, efficacious agricultural H5N3 vaccine by reverse genetics. Virology, 314, 580-90.

Longini, I. M., Jr., Nizam, A., Xu, S., Ungchusak, K., Hanshaoworakul, W., Cummings, D. A., \& Halloran, M. E. (2005). Containing pandemic influenza at the source. Science, 309, 1083-7.

Maines, T. R., Lu, X. H., Erb, S. M., Edwards, L., Guarner, J., Greer, P. W., Nguyen, D. C., Szretter, K. J., Chen, L. M., Thawatsupha, P., Chittaganpitch, M., Waicharoen, S., Nguyen, D. T., Nguyen, T., Nguyen, H. H., Kim, J. H., Hoang, L. T., Kang, C., Phuong, L. S., Lim, W., Zaki, S., Donis, R. O., Cox, N. J., Katz, J. M., \& Tumpey, T. M. (2005). Avian influenza (H5N1) viruses isolated from humans in Asia in 2004 exhibit increased virulence in mammals. $J$ Virol, 79, 11788-800.

Matrosovich, M., Zhou, N., Kawaoka, Y., \& Webster, R. (1999). The surface glycoproteins of H5 influenza viruses isolated from humans, chickens, and wild aquatic birds have distinguishable properties. J Virol, 73, 1146-55.

OIE. (2005). Update on avian influenza in animals (type H5). Date of updating: 10 October 2005. World Organization for Animal Health. Date of access: 11 November 2005, http://www.oie. int/downld/AVIAN\%20INFLUENZA/A_AI-Asia.htm

Puthavathana, P., Auewarakul, P., Charoenying, P. C., Sangsiriwut, K., Pooruk, P., Boonnak, K., Khanyok, R., Thawachsupa, P., Kijphati, R., \& Sawanpanyalert, P. (2005). Molecular characterization of the complete genome of human influenza H5N1 virus isolates from Thailand. J Gen Virol, 86, 423-33.

Rimmelzwaan, G. F., Kuiken, T., van Amerongen, G., Bestebroer, T. M., Fouchier, R. A., \& Osterhaus, A. D. (2001). Pathogenesis of influenza A (H5N1) virus infection in a primate model. J Virol, 75, 6687-91.

Rimmelzwaan, G. F., Kuiken, T., van Amerongen, G., Bestebroer, T. M., Fouchier, R. A., \& Osterhaus, A. D. (2003). A primate model to study the pathogenesis of influenza A (H5N1) virus infection. Avian Dis, 47, 931-3.

Songsermn, T., Amonsin, A., Jam-on, R., Sae-Heng, N., Meemak, N., Pariyothorn, N., Payungporn, S., Theamboonlers, A., \& Poovorawan, Y. (2006). Avian influenza H5N1 in naturally infected domestic cat. Emerg Infect Dis, 12, 681-3.

Sturm-Ramirez, K. M., Hulse-Post, D. J., Govorkova, E. A., Humberd, J., Seiler, P., Puthavathana, P., Buranathai, C., Nguyen, T. D., Chaisingh, A., Long, H. T., Naipospos, T. S., Chen, H., Ellis, T. M., Guan, Y., Peiris, J. S., \& Webster, R. G. (2005). Are ducks contributing to the endemicity of highly pathogenic H5N1 influenza virus in Asia? J Virol, 79, 11269-79.

Suzuki, Y. (2005). Sialobiology of influenza: Molecular mechanism of host range variation of influenza viruses. Biol Pharm Bull, 28, 399-408.

Swayne, D. E., Beck, J. R., Perdue, M. L., \& Beard, C. W. (2001). Efficacy of vaccines in chickens against highly pathogenic Hong Kong H5N1 avian influenza. Avian Dis, 45, 355-65.

Thanawongnuwech, R., Amonsin, A., Tantilertcharoen, R., Damrongwatanapokin, S., Theamboonlers, A., Payungporn, S., Nanthapornphiphat, K., Ratanamungklanon, S., Tunak, E., Songserm, T., 
Vivatthanavanich, V., Lekdumrongsak, T., Kesdangsakonwut, S., Tunhikorn, S., \& Poovorawan, Y. (2005). Probable tiger-to-tiger transmission of avian influenza H5N1. Emerg Infect Dis, 11, 699-701.

Tian, G., Zhang, S., Li, Y., Bu, Z., Liu, P., Zhou, J., Li, C., Shi, J., Yu, K., \& Chen, H. (2005). Protective efficacy in chickens, geese and ducks of an H5N1-inactivated vaccine developed by reverse genetics. Virology, 341, 153-62.

Tiensin, T., Chaitaweesub, P., Songserm, T., Chaisingh, A., Hoonsuwan, W., Buranathai, C., Parakamawongsa, T., Premashthira, S., Amonsin, A., Gilbert, M., Nielen, M., \& Stegeman, A. (2005). Highly pathogenic avian influenza H5N1, Thailand, Emerg Infect Dis, 11, 1664-72.

Uiprasertkul, M., Puthavathana, P., Sangsiriwut, K., Pooruk, P., Srisook, K., Peiris, M., Nicholls, J. M., Chokephaibulkit, K., Vanprapar, N., \& Auewarakul, P. (2005). Influenza A H5N1 replication sites in humans. Emerg Infect Dis, 11, 1036-41.

Ungchusak, K., Auewarakul, P., Dowell, S. F., Kitphati, R., Auwanit, W., Puthavathana, P., Uiprasertkul, M., Boonnak, K., Pittayawonganon, C., Cox, N. J., Zaki, S. R., Thawatsupha, P., Chittaganpitch, M., Khontong, R., Simmerman, J. M., \& Chunsutthiwat, S. (2005). Probable person-to-person transmission of avian influenza A (H5N1). N Engl J Med, 352, 333-40.

Viseshakul, N., Thanawongnuwech, R., Amonsin, A., Suradhat, S., Payungporn, S., Keawchareon, J., Oraveerakul, K., Wongyanin, P., Plitkul, S., Theamboonlers, A., \& Poovorawan, Y. (2004). The genome sequence analysis of H5N1 avian influenza A virus isolated from the outbreak among poultry populations in Thailand. Virology, 328, 169-76.

Wibulpolprasert, S., Chunsuttiwat, S., Ungchusak, K., Kanchanachitra, C., Teokul, W., \& Prempree, P. (Eds). (2005). National strategic plan for avian influenza control and influenza pandemic preparedness in Thailand, 2005-2007. The Ministry of Public Health and the Thai Health Promotion Foundation, Thailand. 